\title{
Religiosidad y bultos sagrados en la Mixteca prehispánica
}

\author{
Manuel A. Hermann Lejarazu
}

El culto al bulto sagrado es una de las actividades rituales que mayor presencia tiene en diversas partes de Mesoamérica. Existen numerosas descripciones y representaciones de bultos sagrados en fuentes coloniales y en documentos pictográficos prehispánicos, siendo la región de la Mixteca la que mayor cantidad de ejemplos presenta. Este aspecto de la religiosidad mixteca manifestada a través de los bultos se puede encontrar en rituales de fundación, en ceremonias de entronización de los gobernantes, en las fiestas periódicas que involucraban a toda la comunidad, pero también en cultos particulares o privados que realizaba el dueño de algún bulto. Al parecer, el culto a los fardos sagrados estaba tan extendido en la Mixteca que quizá constituyó la principal manifestación religiosa de esta región en la época prehispánica.

PALABRAS CLAVE: bultos sagrados, Mixteca, códices, religiosidad, rituales

\section{Religiousness and Sacred Bundles in Prehispanic Mixteca}

The sacred bundle cult is one of the most widespread ritual activities throughout Mesoamerica. There is an abundant number of descriptions and representations of sacred bundles both in colonial sources and prehispanic pictographic documents, and the Mixteca region houses the greatest number of them. The use of bundles in Mixtec religiousness took place in foundational rituals, ceremonies of the accession of rulers, and periodical ceremonies that involved the whole community, but also in particular or private cults organized by the owner of a specific bundle. It appears that the sacred bundle cult was so widespread in the Mixteca that it might have been the main religious manifestation of the region during the prehispanic period.

KEY WORDS: sacred bundles, Mixteca, codices, religiousness, rituals

ManUel A. Hermann LejaraZu: Centro de Investigaciones y Estudios Superiores en Antropología Social, México-Distrito Federal hermann@ciesas.edu.mx 
$\mathrm{E}$ 1 culto al bulto sagrado es una de las actividades rituales que se llegaron a practicar de manera frecuente en diversas partes de Mesoamérica. Existen numerosas representaciones y descripciones de bultos sagrados en estelas, dinteles, códices y manuscritos del mundo nahua, maya, quiché, zapoteco y mixteco, lo que demuestra su gran importancia como fenómeno religioso a través del tiempo. Particularmente, en los códices mixtecos se han documentado diversos tipos de bultos que aluden a las deidades asociadas con ellos, aunque en otras ocasiones los fardos están relacionados con objetos o instrumentos empleados en alguna ceremonia en particular.

Para la Mixteca prehispánica no se han elaborado análisis detallados sobre los envoltorios representados en los códices, ni tampoco se ha explorado su profunda trascendencia como manifestación religiosa. Es por ello que en el presente trabajo indagaremos sobre los aspectos más sobresalientes del culto al bulto sagrado entre los mixtecos de la época prehispánica y del periodo colonial temprano con el objetivo de trazar algunos rasgos que nos permitan adentrarnos en el pensamiento religioso plasmado en estos pueblos del sur de México.

Debido a la importancia de los bultos sagrados en Mesoamérica actualmente contamos con diversos trabajos dedicados a esclarecer su significado. Entre los estudios más destacados podemos mencionar a Stenzel (1972), quien realizó una interesante comparación entre los bultos de los pueblos de Norteamérica y los mesoamericanos. El austriaco Karl Anton Nowotny $(1961,1966)$ identificó varias imágenes de envoltorios en los códices del grupo Borgia y también se percató de las similitudes entre los bultos norteamericanos y los de Mesoamérica. Alfredo López-Austin (1973) destacó el nexo entre los envoltorios y los dioses patronos de algún pueblo o comunidad durante sus procesos migratorios. En los últimos años, Nelly Gutiérrez (1986) ha vuelto a señalar la importancia de este tipo de objetos en la religión mesoamericana. John Pohl (1994) retomó los datos que hay sobre este tema en la etnografía estadounidense y los compara, en términos religiosos, con la información existente para la Mixteca prehispánica. Guilhem Olivier (1995 y 2006) hace un análisis muy completo sobre el significado de los bultos y señala su papel dentro de los ritos de entronización de los tlahtoque mexicas. En un trabajo reciente, Olivier (2007) identifica la importancia de los bultos sagrados en el Mapa de Cuauhtinchan 2 y los relaciona con las ceremonias en las que se encendía el fuego nuevo. Por último, hay que mencionar la destacada obra colectiva de Guernsey y Kent Reilly III (2006) sobre los rituales en torno a los envoltorios y atados en la religión mesoamericana.

Para el mundo maya podemos señalar el estudio de Merle Greene (1972) sobre los bultos representados en los monumentos de Yaxchilán; y el de Maricela Ayala (2002), quien realiza un exhaustivo trabajo a partir del descubrimiento de un envoltorio encontrado en las excavaciones arqueológicas del sitio conocido como Mundo Perdido, en Tikal. Recientemente, Freidel y Paul Guenter (2006) abordan el papel de los bultos y los lugares de entronización de los gobernantes mayas.

Para el desarrollo del presente artículo no será posible abundar en todas estas investigaciones sobre los envoltorios en Mesoamérica; sin embargo, intentaremos realizar algunas asociaciones y comparaciones entre la información existente en la Mixteca con la de algunos otros pueblos del mundo nahua o maya, según sea necesario. Todo ello para esclarecer el significado y la importancia de los bultos sagrados en la religión mixteca de acuerdo con lo que hemos recopilado en diversos códices y otros documentos históricos.

\section{TNANI, ÑOHO DZUCU O TLAQUIMILOLLI}

De acuerdo con algunos diccionarios o vocabularios que registraron las lenguas indígenas de Mesoamérica, es posible conocer el nombre original que los antiguos mixtecos o nahuas dieron a los bultos sagrados. Para los nahuas, el fardo divino se conocía como tlaquimilolli o quimili, que viene del verbo quimiloa, "liar o envolver algo en manta” (Molina, 2001: 90r), o también de tlaquimilhuia, "envolver o liar algo a otro" (ibidem: 134 r). De manera que tlaquimilolli, de acuerdo con fray Alonso de Molina, es "cosa liada assi" (ibidem: 134r), y quimili es "lío de ropa o mantas" (ibidem: 90r). Por lo tanto, el nombre en náhuatl se refiere tanto a la acción de envolver en mantas como al envoltorio de mantas mismo. 
Para la lengua mixteca contamos con el Vocabulario de fray Francisco de Alvarado (1962), quien registró la entrada "emboltorio de manta" como tnani, dzoo nicuvni tnani y dzoo niquidza tnani (Alvarado, 1962: 88v.). La palabra dzoo significa "manta", y los verbos nicuvni y niquidza pueden traducirse como "hecho" o "hizo", por lo que el vocablo dzoo nicuvni tnani quiere decir "manta hecha envoltorio"; así, la palabra tnani se refiere al nombre mixteco del envoltorio.

Otras entradas de Alvarado refuerzan esta idea, tales como "emboltorio hacer asi", yosaqtnani dzoo, yoquidza tnani (Alvarado, 1962: 88v), aunque también aparecen los vocablos dzucu o ñoho dzucu en "embolver algo como quiera": yotniño dzucundi, yodzucu ninondi (ibidem: 88v.); o en "embuelta cosa": sañohodzucu, sanisacoho dzucu (ibidem). Es probable que, en mixteco, la acción de "envolver" refiera a las palabras $d z u c u$, ñoho $d z u c u$, mientras que el envoltorio de mantas es tnani.

No obstante, es necesario revisar las imágenes mismas de los envoltorios o bultos sagrados en los códices para dilucidar una acepción adecuada sobre el nombre en mixteco.

\section{REPRESENTACIONES ICONOGRÁFICAS}

Los bultos en los códices mixtecos aparecen frecuentemente representados en forma redonda u ovalada, por lo que, al parecer, reflejan una imagen naturalista de los envoltorios reales que se resguardaban en los templos (fig. 1). Aunque es difícil saberlo con entera certeza — pues únicamente podemos basarnos en las descripciones de algunas fuentes o en las figuras plasmadas en los códices-, creemos, en general, que la mayoría de los bultos tenían este aspecto redondo y voluminoso a causa de los materiales que le daban forma.

Según observamos en los diccionarios de náhuatl y mixteco mencionados arriba, los términos indígenas quimili y tnani aluden directamente a un "envoltorio de mantas", por lo que las figuras dibujadas en los códices muestran los bultos completamente amarrados con unas cuerdas en la parte superior y que sujetaban, sin duda, las mantas que servían para hacer el envoltorio.
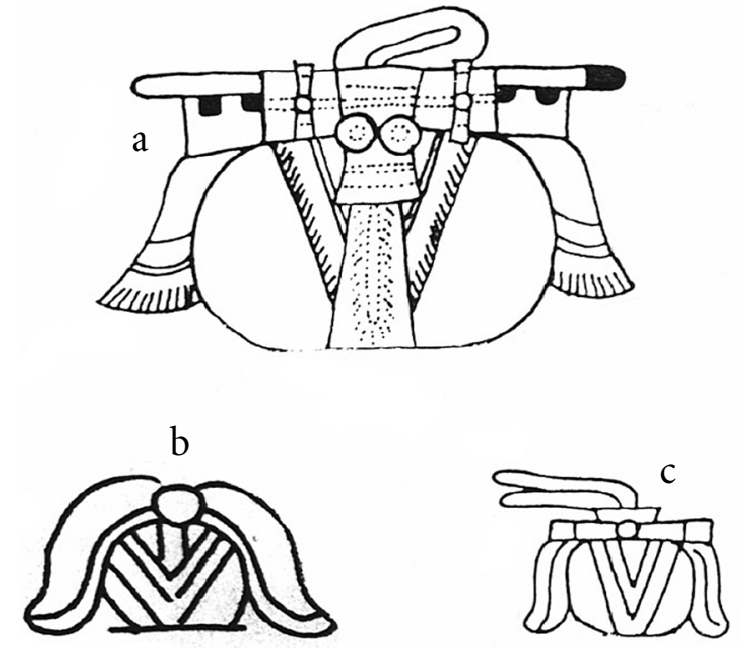

Figura 1. a) Nuttall 83; b) Colombino 5; c) Bodley 25.

Según se observa en algunos códices, las cuerdas amarradas llegaban a caer por ambos extremos del envoltorio y eran colocados uno o varios moños de papel plegado arriba de ellos ${ }^{1}$; pero en otras imágenes, una especie de paño adicional parece cubrir por completo al bulto. En el Códice Nuttall ${ }^{2}$, por ejemplo, se encuentra un bulto asociado a los instrumentos para encender el fuego (fig. 1a) y en él se ve el dibujo de una tela o paño que sobresale de ambos lados por la parte superior. Además, en documentos como el Códice Colombino y Becker $1^{3}$ encontramos una gruesa tela de color rojo que cubre casi completamente el bulto redondo (fig. 1 b).

En otras representaciones, una pequeña manta en forma triangular atraviesa la parte central del fardo como si fuera una última cubierta que lo envuelve. En la mayoría de las ocasiones, esta manta triangular aparece pintada de rojo y blanco, o de rojo y amarillo.

\footnotetext{
${ }^{1}$ En el estudio que realiza sobre los bultos del Mapa de Cuauhtinchan 2, Olivier (2007: 292) señala que, para el mundo nahua, el papel doblado en tiras de color rojo y blanco colocado sobre los bultos está relacionado con el fuego, el sacrificio, la Serpiente de Fuego y con deidades como Mixcóatl y Xiuhtecuhtli.

${ }^{2}$ El Códice Nuttal puede consultarse en Anders et al., 1992.

${ }^{3}$ Los códices Colombino y Becker pueden consultarse en Caso, 1966 y Troike, 1974, respectivamente.
} 

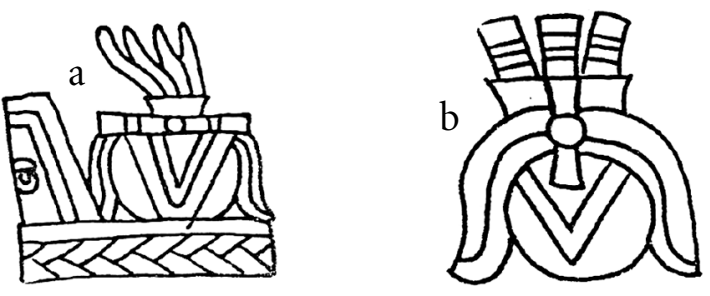

Figura 2. a) Bodley 21; b) Becker 9.

Según observamos en varias páginas de los códices, algunos bultos eran adornados con plumas de quetzal en la parte superior (tal y como aparece en el Bodley ${ }^{4}$, fig. 2a), o con recortes de papel o tiras de tela colocadas también por arriba, como aparece en el Becker 1 (fig. 2b). En este sentido, los bultos que aparecen con recortes de papel plegado en la parte superior (como es el caso de la fig. 1a) están relacionados, al parecer, con la ceremonia del fuego nuevo (Olivier, 2007: 287-302). Pero sobre este tipo de bultos regresaremos posteriormente.

Indudablemente, los bultos circulares blancos indican que las mantas que conformaban los fardos no estaban teñidas, sino que conservaban el blanco natural del algodón o de algún otro material. Sin embargo, existen representaciones en las que el bulto aparece en diferentes colores; por ejemplo, en el Códice Colombino el fardo está pintado de color azul cubierto por otras telas en color rojo (fig. 1b, p. 77). En el Becker 1 el bulto redondo es rojo (fig. 2b), y en el Bodley (fig. 1c, p. 77) suele aparecer también pintado en azul, lo que hace suponer que en todos estos casos las mantas estaban teñidas con esos colorantes.

No obstante, no todos los bultos reportados en Mesoamérica fueron elaborados con mantas de algodón. Maricela Ayala señala que el envoltorio hallado en Mundo Perdido, Tikal, estaba hecho de papel amate y, de acuerdo con los restos conservados, estaba pintado de azul (Ayala, 2002: 34).

Sin embargo, según lo analizado hasta el momento, pensamos que los bultos dibujados en los códices mixtecos representan aquéllos elaborados con mantas envuel-

${ }^{4}$ El Códice Bodley puede consultarse en Caso, 1960. tas, por lo que nos inclinamos a pensar que el vocablo mixteco tnani es el término que refiere al fardo, y no los términos $d z u c u$ o ñoho $d z u c u$, que implican la acción de "envolver".

\section{CONTENIDO}

El contenido de los bultos o envoltorios sagrados está extensamente documentado en fuentes prehispánicas y en escritos coloniales a lo largo de diversas regiones de Mesoamérica. Incluso podemos decir que el contenido era tan variado que no es posible circunscribirlo a un solo elemento. Del mundo nahua provienen descripciones muy completas acerca del contenido de los bultos sagrados. Por ejemplo, el cronista Juan Bautista de Pomar refiere, en su Relación geográfica de 1582, la existencia de dos bultos muy reverenciados en la ciudad de Tezcoco (Acuña, 1986, t. III: 59).

Según Pomar, los bultos estaban resguardados en un aposento llamado tlacatecco, ubicado a un lado del templo mayor de Tezcoco. Nos dice:

Junto al cu y templo mayor, había una sala y aposento que llamaban tlacatecco, que se interpreta por 'casa de hombres de dignidad', en donde se guardaban, por cosas principalísimas y divinas, dos envoltorios o líos de muchas mantas muy ricas y muy blancas: el uno, del ídolo de Tezcatlipoca, y el otro, de Huitzilopochtli. En el de Tezcatlipoca estaba un espejo de alinde, del tamaño y compás de una media naranja grande, engastado en una piedra negra tosca. Estaban, con ella, muchas piedras ricas sueltas, como eran chalchihuites, esmeraldas, turquesas, y de otros muchos géneros. Y la manta que estaba más cercana del espejo y piedra era pintada de osamenta humana (Acuña, 1986, t. III: 59).

De acuerdo con lo que nos dice este autor, el bulto de Tezcatlipoca tenía como contenido el espejo o tezcatl —emblema característico de esta deidad-, junto con otras piedras preciosas. En cuanto al de Huitzilopochtli, continúa describiendo el autor, el contenido eran dos espinas de maguey atadas o envueltas en muchas mantas (Acuña, op. cit.).

Otro historiador indígena de finales del siglo XVI, Cristóbal del Castillo, escribió una asombrosa relación 
histórica sobre la salida y migración de los mexicas al partir de un lugar llamado Aztlán-Chicomóztoc (Castillo, 2001). Toda la peregrinación, de acuerdo con Del Castillo, era guiada por un gobernante llamado Huitzilópoch, quien tenía la facultad de poder hablar con Tetzauhtéotl, el dios patrono de los mecitin. Cuando los migrantes llegan a Culhuacan, Huitzilópoch muere por su avanzada edad y su cuerpo es depositado en una caja de piedra de la cual, después de cuatro años, sus restos fueron extraídos y colocados dentro de un bulto (op. cit.: 121 y 123). Es decir, los huesos de Huitzilópoch funcionaron como una morada para que residiera en ellos la deidad principal y por medio de los cuales Tetzauhtéotl podría comunicarse y manifestar sus designios a los sacerdotes encargados del envoltorio. De esta manera, el guía y gobernante deificado llevaría el nombre de Huitzilopochtli-Tetzauhtéotl.

De acuerdo, entonces, con esta descripción, el famoso bulto sagrado de Huitzilopochtli contenía los huesos de un personaje llamado Huitzitl o Huitzilópoch que se había convertido, tras su muerte, en la imagen o representante del dios tutelar de los mexicas, llamado en esta fuente Tetzauhtéotl. De esta manera, dios y hombre-dios estaban unidos por medio de los huesos que conformaban el contenido del envoltorio sagrado.

Según otras descripciones, como la de fray Gerónimo de Mendieta, algunos bultos se formaron a partir de las mantas o vestimentas de los dioses sacrificados en tiempos primigenios para darle movimiento al sol (Mendieta, 2002, vol. 1: 184). A decir del cronista, estas vestimentas fueron envueltas por los primeros sacerdotes o seguidores de las deidades junto con algunos palos que tenían en su interior piedras de chalchihuite y pieles de serpiente y jaguar (loc. cit.).

Un último ejemplo lo encontramos en la Historia de Tlaxcala de Diego Muñoz Camargo, quien refiere la existencia de un bulto sagrado en poder de Gonzalo Tecpanécatl, señor de la parcialidad de Tepeticpac (Muñoz Camargo, 1998: 235-236). Según nos menciona este autor, el cacique indígena poseía las cenizas del dios Camaxtle, patrono de los tlaxcaltecas, en un pequeño adoratorio en el interior de su casa. Cuando Gonzalo Tecpanécatl entrega el envoltorio a fray Diego de Olarte, guardián de

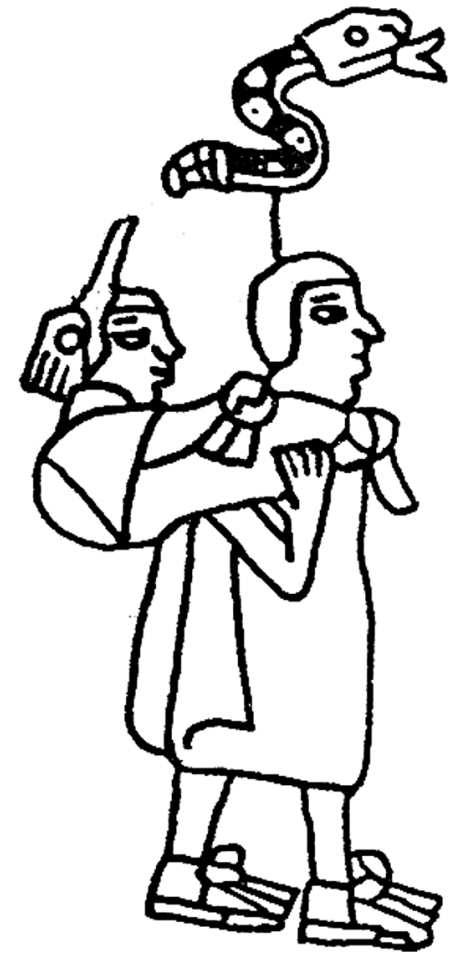

Figura 3. Códice Boturini, lam. 2.

Tlaxcala, éste lo desata y encuentra, además de las cenizas, un pequeño cofre de palo con un chalchihuitl y cabellos rubios que pertenecieron a Camaxtle (loc. cit.).

Dentro de la iconografía nahua encontramos varias representaciones de bultos sagrados que muestran el contenido de cada uno de ellos. En la lámina 2 del Códice Boturini (1991) se representa una extraordinaria escena en la que aparecen cuatro teomamaque o cargadores de dioses que parecen encabezar la migración mexica tras su paso por Culhuacán. Uno de los cargadores lleva a cuestas un bulto en cuyo borde superior se asoma una imagen que representa a Huitzilopochtli, la deidad protectora del grupo (fig. 3).

Si bien para la región mixteca adolecemos de fuentes y crónicas escritas por indígenas o frailes españoles, afortunadamente contamos con algunas descripciones en otros documentos que se refieren al contenido de los bultos tanto entre los zapotecos como en otros grupos oaxaqueños. 
Entre los ixcatecos existía un importante culto a dos bultos sagrados que contenían los ídolos o deidades adorados por la población (Acuña, 1984, t. I: 230). Según se menciona en la Relación geográfica de Ixcatlán, los dos ídolos estaban hechos de piedra verde, forrados en mantas y estaban metidos dentro unos cestos resguardados
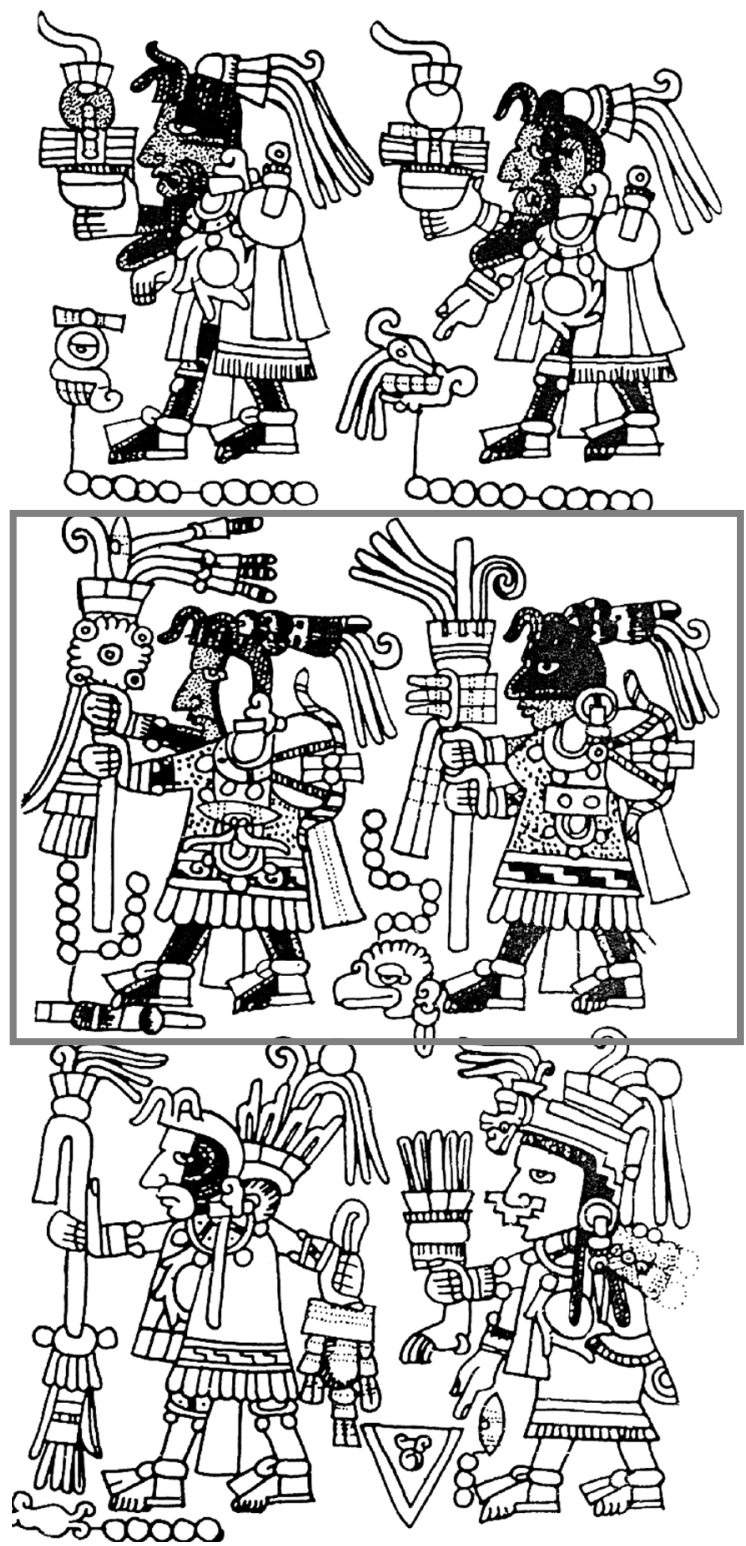

Figura 4. Códice Nuttall 15-I. por los sacerdotes. Los dos bultos permanecían ocultos en el templo y eran sacados únicamente durante las fiestas del año para recibir las ofrendas del pueblo (loc. cit.).

Según menciona fray Francisco de Burgoa, en el pueblo zapoteco de Quiegolani existía un importantísimo culto a un envoltorio cuyo contenido era una mazorca. De acuerdo con su descripción, durante la cosecha de maíz los zapotecos escogían la mazorca más grande y de mejor grano que se había dado ese año para ofrendarla como deidad. La mazorca era colocada en un altar a la que le dedicaban ceremonias, sacrificios, cantos y bailes. Incluso, la mazorca misma era vestida con ropa a su medida a la que le ponían piedras verdes como adornos. Una vez terminadas las ceremonias, la mazorca era envuelta en un lienzo blanco de algodón y se guardaba hasta la temporada de siembras. Entonces los sacerdotes llevaban el bulto al lugar donde se encontraban las milpas y lo ponían dentro de un cuero de venado para enterrarlo en un hoyo justamente en medio de los sembradíos (Burgoa, 1997a, t. 2: 332 r y v).

\section{CONTENIDO DE LOS BULTOS EN LOS CÓDICES MIXTECOS}

\section{Bulto de 9 Viento Quetzalcóatl}

Con base en estas detalladas descripciones, no nos cabe la menor duda sobre la variedad de bultos que existían y los diferentes rituales a los que estaban dedicados. En los códices mixtecos he podido identificar, de acuerdo con su contenido, cuatro diferentes bultos que, probablemente, aluden tanto al culto particular hacia una deidad como a los objetos relacionados con ellos.

En la mayoría de imágenes que existe sobre el tnani o envoltorio en los códices, éste aparece únicamente con uno o varios moños en la parte superior y con las telas o cuerdas que los sujetaban. En estos bultos no podemos identificar el contenido debido a que no se dibujó encima de ellos ninguna figura o efigie que indique el culto al que estaba relacionado. Sin embargo, en otras ocasiones el contexto de la narrativa nos ayuda a identificar el contenido del bulto. 
En las páginas 14 y 15 del Códice Nuttall aparecen representados varios envoltorios que son transportados por dos sacerdotes llamados 10-Caña y 10-Zopilote (fig. 4). El contenido del bulto se revela en la página 15-II, en la que encontramos dibujado un gran fardo redondo con la imagen de un cuchillo de pedernal y un rostro o cara que se asoma desde su interior. Se trata del envoltorio sagrado del Señor 9-Viento "Quetzalcóatl", al que podemos identificar por el nombre calendárico y por el lugar donde está colocado: el Templo de la Serpiente Emplumada (fig. 5). Este lugar, al parecer, estaba destinado como asiento o pueblo para la Señora 3-Pedernal y el Señor 5-Flor, protagonistas de estas páginas del Códice Nuttall, quienes habían emprendido una peregrinación acompañados por cuatro sacerdotes.

El hecho de que el bulto sagrado esté relacionado con la representación de un gran pedernal nos remite sin duda al mito narrado en el Códice Vindobonensis (1974), en el que se menciona el nacimiento de Quetzalcóatl precisamente de un gran pedernal. Así, el contenido del envoltorio era el pedernal del que había nacido la deidad, por lo que, en varias ocasiones, a lo largo del Códice Nuttall, se identifica a Quetzalcóatl con este mismo material.

\section{Bulto con instrumentos para encender fuego}

Sin embargo, al parecer, no todos los bultos sagrados contenían reliquias u objetos relacionados con una deidad. Continuando con nuestro análisis de las páginas 14 a 15 del Nuttall, nos hemos percatado de que uno de los envoltorios cargados por los sacerdotes que acompañan a la Señora 3-Pedernal lleva sobrepuestos los instrumentos para encender el fuego. Si efectivamente la figura o imagen colocada encima del bulto nos refiere al contenido, tal y como vimos en el caso de 9-Viento Quetzalcóatl, entonces, el tnani en cuestión contenía el madero horadado y el taladro para producir el fuego. En la página 14-I del Nuttall se observa claramente que el sacerdote 10-Caña carga el fardo con los instrumentos para encender el fuego (fig. 6, p. 82), pero nuestra interpretación acerca de que dichos objetos se encontraban dentro del bulto se basa en dos argumentos.

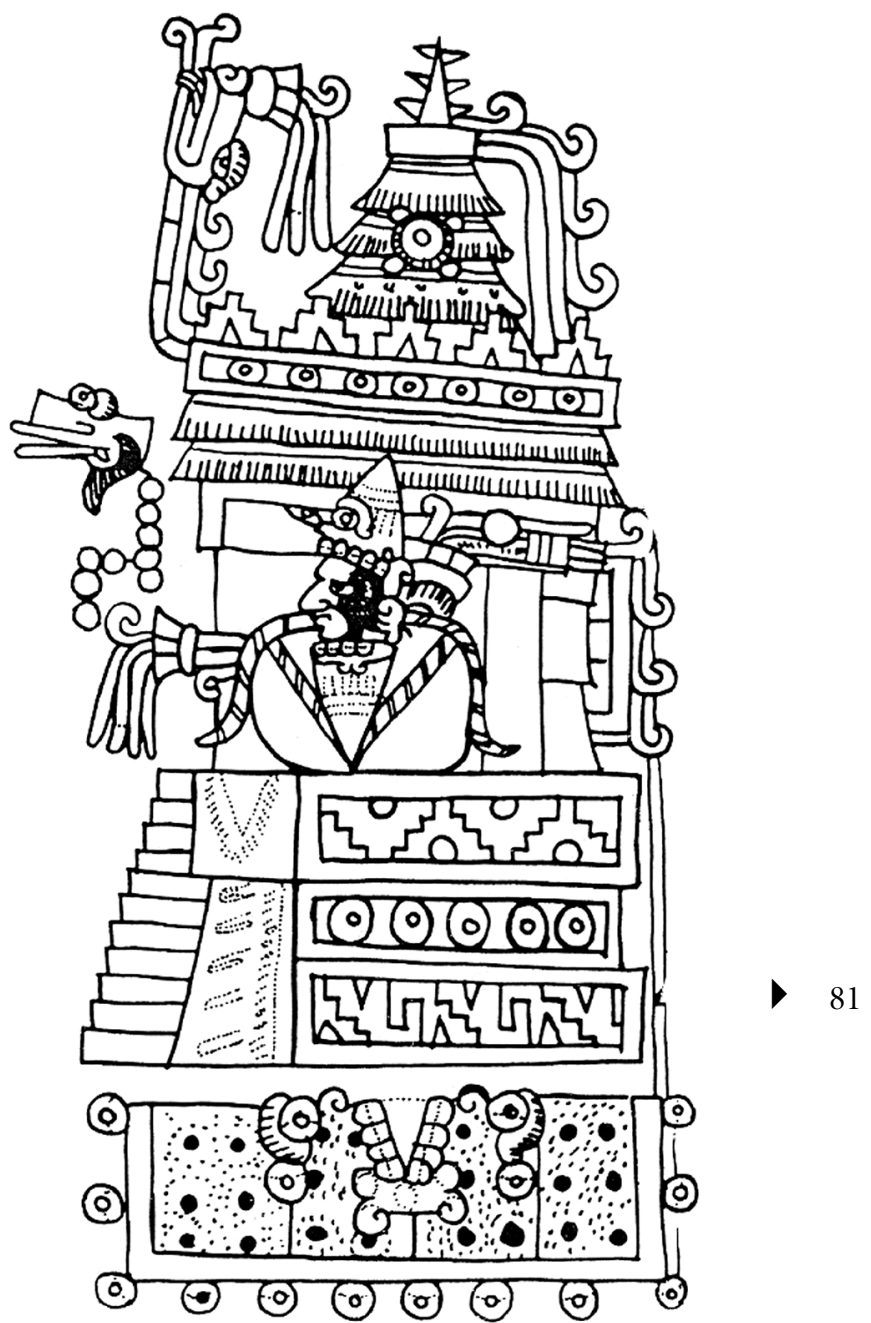

Figura 5. Bulto de 9-Viento Quetzalcóatl. Códice Nuttall 15-II.

El primero proviene nuevamente de las escenas del Códice Nuttall, página 19 (fig. 7, p. 83), donde el Señor 12Viento, antes de su matrimonio con la Señora 3-Pedernal (hija de la Señora 3-Pedernal antes mencionada), recibe en el cielo, de manos de los dioses 4-Lagarto y 11Lagarto, un pequeño templo o casa y el madero horadado con la caña o taladro. 12-Viento desciende del cielo por medio de una cuerda acompañado de cinco personajes que fungen como sus acompañantes o sacerdotes. Todos cargan los símbolos sagrados de fundación, junto con otros instrumentos de culto. Uno de los sacerdotes que 


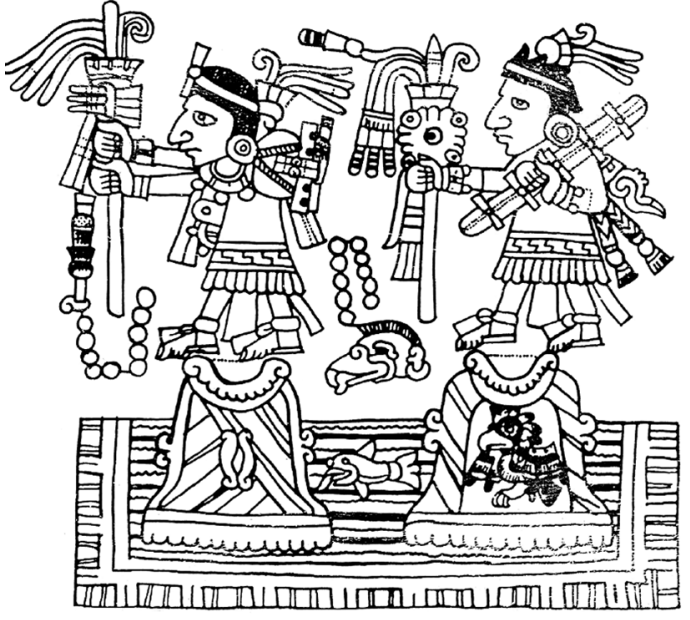

Figura 6. 10-Zopilote carga el bulto con los instrumentos para encender el fuego. Códice Nuttall 14.

acompaña a 12-Viento en su descenso lleva por nombre 5-Perro "Flecha Emplumada" y porta en su espalda precisamente un bulto circular con el madero y el taladro encima. Esto nos lleva a pensar que se trata de los mismos ron transportados por sus acompañantes del cielo a la tierra envueltos en mantas. Como complemento, el Señor 12-Viento carga en su espalda el pequeño templo o casa, también entregado por los dioses, que servirá como recinto sagrado para albergar al bulto divino. Sin duda, todos estos acontecimientos ocurrieron en una etapa primordial, cuando se comenzaban a fundar los primeros pueblos y las primeras genealogías.

El segundo argumento plantea que el contenido de estos bultos eran los instrumentos para hacer el fuego, que proviene de fray Juan de Torquemada (1975). Según el relato del cronista franciscano, durante la peregrinación de los mexicas aparecieron dos pequeños envoltorios o quimiles en un lugar llamado Cohuatlycamac. Uno de los envoltorios contenía una piedra preciosa que resplandecía como esmeralda, la cual inmediatamente fue objeto de disensiones y contiendas entre los mexicas por su posesión. En cuanto al segundo envoltorio, al desatarlo descubrieron que sólo contenía dos palos, por lo que los mexicas no le hicieron caso, pero con esos palos el guía Huitziton prendió el fuego y les enseñó que esto serviría mucho más que la piedra preciosa (Torquemada, 1975, Monarquía indiana, vol. I, lib. II, cap. II: 115-116).

Por lo tanto, los instrumentos para encender el fuego eran considerados también divinos por los antiguos nahuas y mixtecos, pues fueron empleados tanto para la ceremonia ritual del "fuego nuevo" por parte de los nahuas, como en las ceremonias de fundación y consagración de pueblos y señoríos por parte de los mixtecos. Los instrumentos, entonces, quedaron guardados en los envoltorios y colocados dentro de los templos.

Finalmente, podemos añadir que los moños o recortes de papel plegado dibujados en los bultos, junto con el madero y el taladro, tienen también una estrecha relación con el simbolismo del fuego nuevo tal y como lo descubre Olivier en su estudio del Mapa de Cuauhtinchan 2 (Olivier, 2007: 287-301).

Hasta el momento se ha señalado el contenido de dos bultos que desempeñan un papel muy importante en el establecimiento y fundación de los primeros linajes y dinastías de la Mixteca prehispánica. Anteriormente señalé que he logrado identificar cuatro diferentes bultos en los códices de acuerdo con su contenido, pero es necesario aclarar que estos bultos no eran los únicos que existían en la religión mixteca, ya que, de acuerdo con otros documentos, el contenido de los bultos era muy variado. Antes de tratar este tema, analizaremos a continuación los dos bultos restantes.

\section{Bulto de Dzavui}

Dzavui, el dios de la lluvia para los mixtecos, es sin duda una de las deidades más importantes para los habitantes de esta región. Los mixtecos incluso se denominan a sí mismos como Nuu Dzavui o "El pueblo del dios de la lluvia”, por lo que nos llama la atención la escasez de representaciones de bultos sagrados que contengan una imagen del dios Dzavui.

En la página 3-II del Códice Selden ${ }^{5}$ aparece la representación de un bulto ovalado con la máscara del dios de

\footnotetext{
${ }^{5}$ Para consultar el Códice Selden véase Caso, 1964.
} 
la lluvia en la parte superior. Este bulto está directamente asociado con otro que, al parecer, contiene una flor de maíz (fig. 8, p. 84). El conjunto está relacionado en sí con una serie de ofrendas y envoltorios que son preparados por varios sacerdotes para el Señor 10-Caña "Águila de Fuego", primer gobernante de Jaltepec. Pensamos que el bulto ovalado con la figura de Dzavui o Tláloc seguramente contenía una representación en piedra o en otro

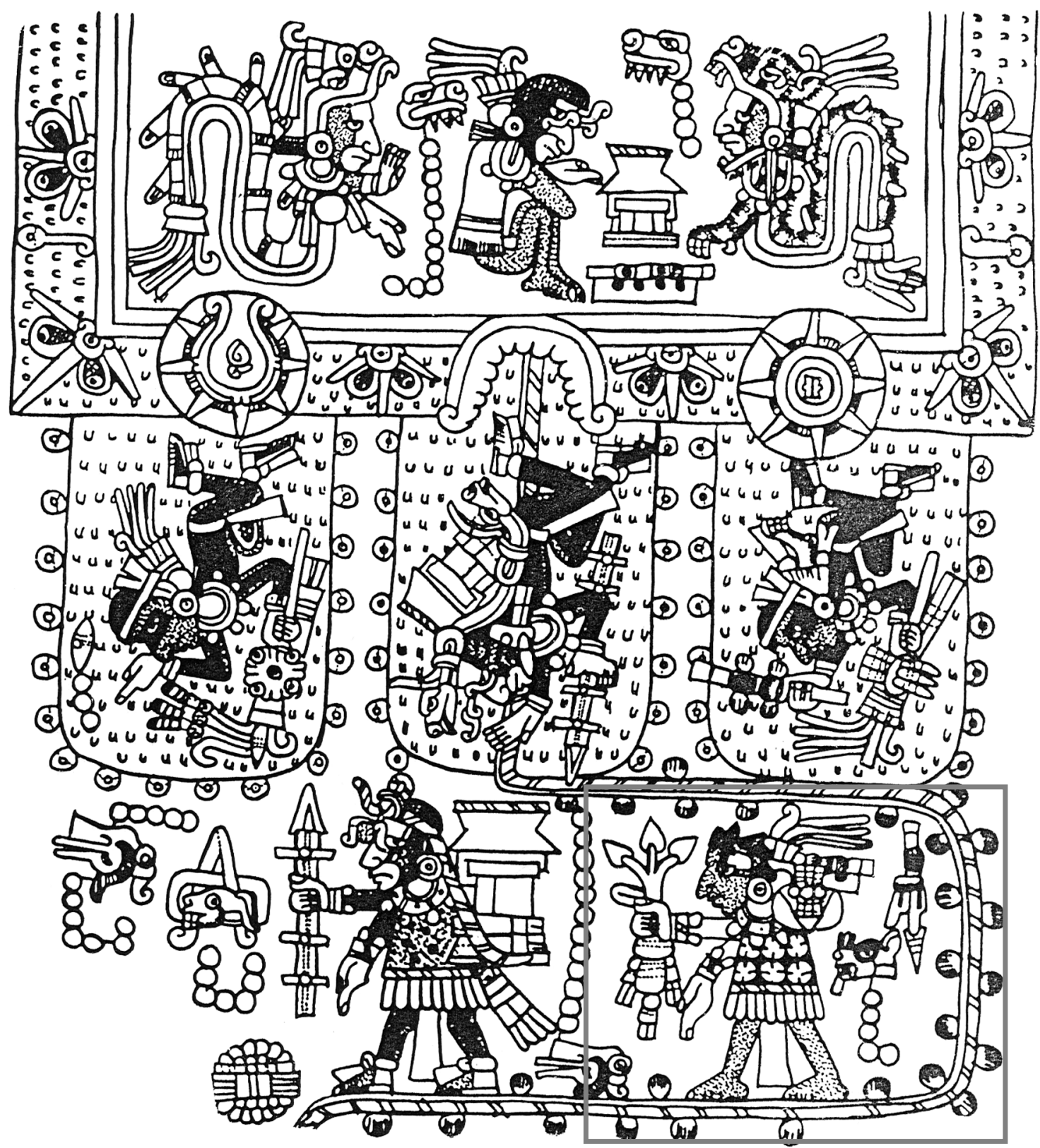



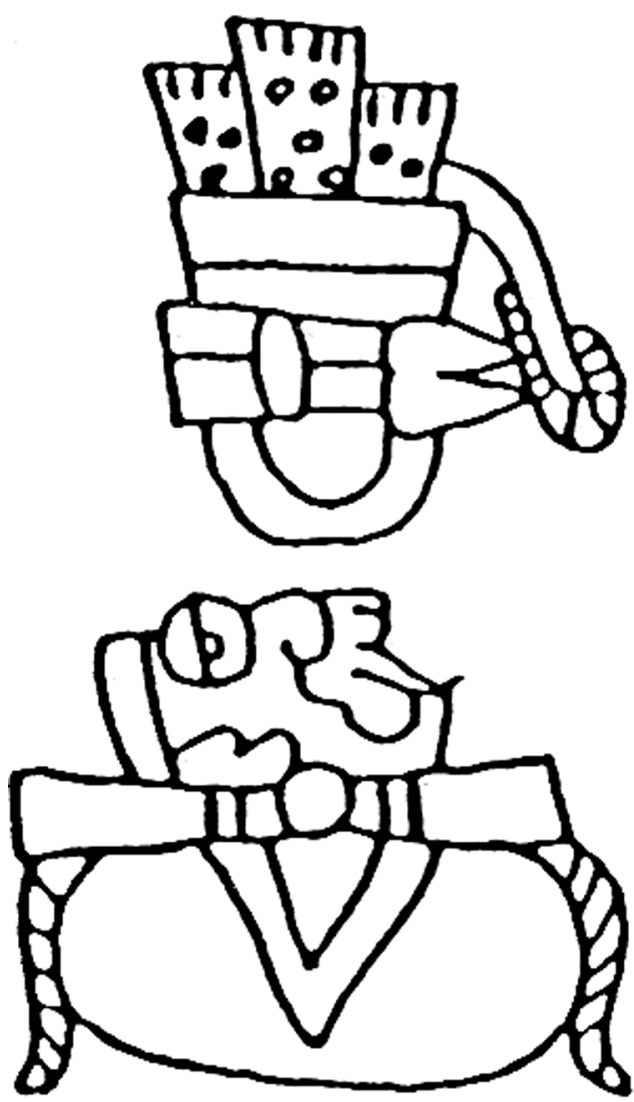

Figura 8. Bulto de maíz y bulto de dzavii. Códice Selden 3-I y II.

material de esta deidad tan importante para los mixtecos. Esto lo mencionamos porque en algunos documentos del siglo XVI se registran los ritos y ceremonias que todavía practicaban los mixtecos en Yanhuitlán a una imagen en piedra denominada Dzavui, que se encontraba envuelta en mantas ${ }^{6}$. Sin embargo, en la representación del tnani del Códice Selden tampoco descartamos la posibilidad de que en su interior haya existido alguna reliquia u objeto simbólico asociado con el dios de la lluvia y no la imagen misma de la deidad.

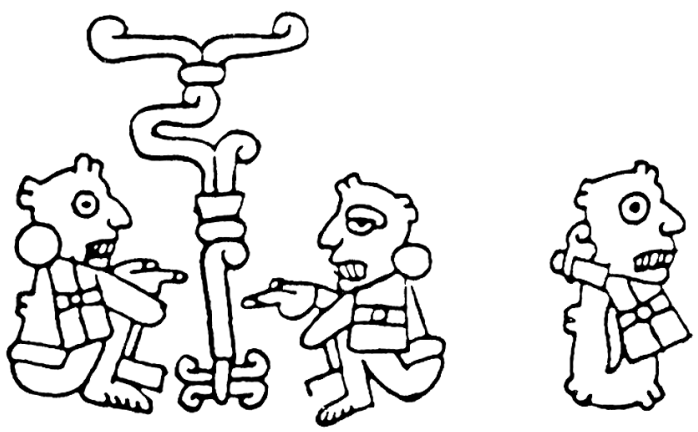

${ }^{6}$ AGN, Ramo Inquisición, vol. 37, exps. 5, 7, 8, 9, 10 y 11.

Figura 9. Representaciones de Nuhu. Códice Vindobonensis 27-II. 


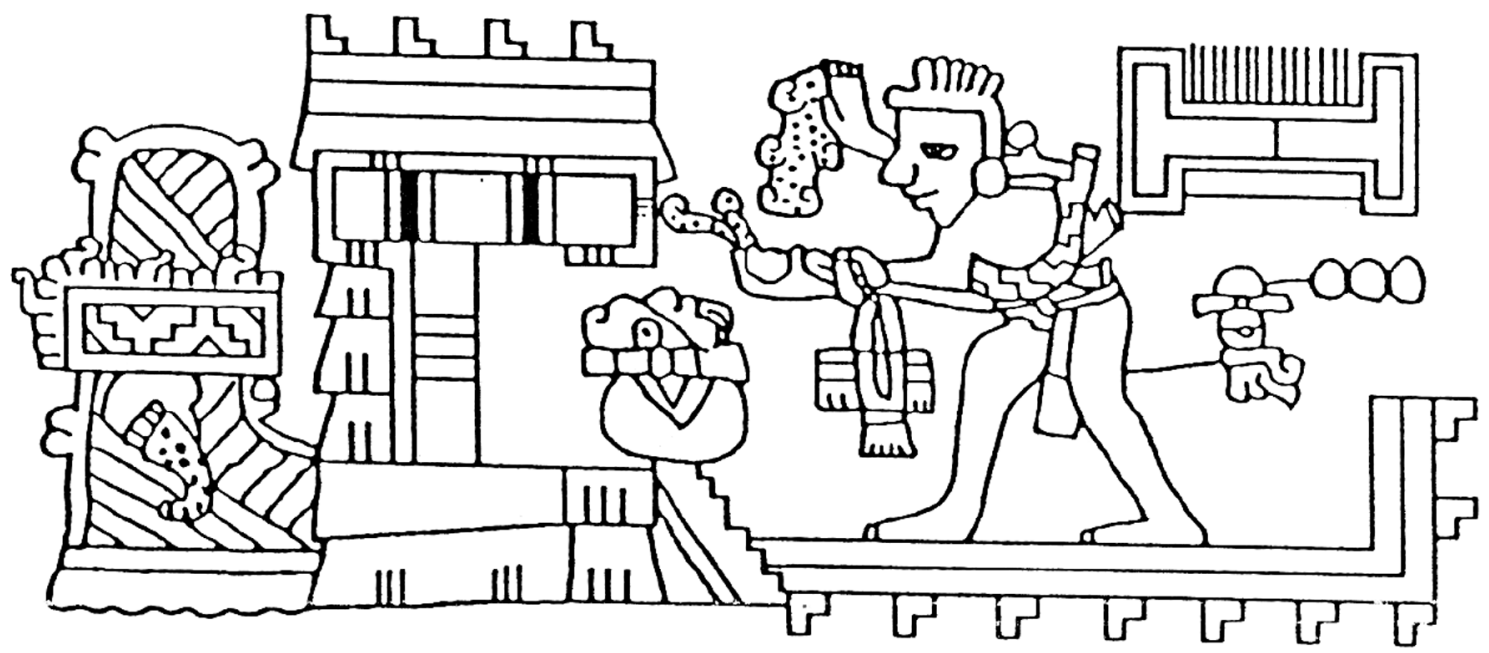

Figura 10. Bulto de ñuhu y ritual de entronización del señor 3-Lluvia en el templo de Jaltepec. Códice Selden 5-II.

del Códice Selden se representa precisamente la visita de varios señores o caciques de pueblos vecinos que le llevan a 10-Caña el bulto redondo de Ñuhu, un escudo, una flecha que también tiene colocada la cabeza de Nuhu y, entre otras cosas, varios instrumentos relacionados, quizá, con sacrificios. Después de una lista de trece pueblos que, al parecer, reconocen el señorío de 10-Caña, vemos a este gobernante vestido como sacerdote entrando al templo de Jaltepec y realizando una serie de ofrendas y autosacrificios delante del envoltorio de Nuhu, como parte de los rituales que conllevaba la toma de poder entre los señores mixtecos.

Finalmente, al cabo de tres años de actividades rituales, el Señor 10-Caña contrajo matrimonio con la Señora 2Lagartija y tomó posesión del señorío. A partir de este momento, y en las generaciones subsecuentes, cada uno de los gobernantes de Jaltepec tenía que realizar ofrendas y autosacrificios al bulto sagrado de su pueblo antes de convertirse en soberano, del mismo modo en que lo hizo el ancestro fundador de la genealogía ${ }^{7}$ ¿ ¿Cual era exactamente el contenido del bulto de Nuhu?

\footnotetext{
${ }^{7}$ Una analogía interesante sobre los ritos de ascenso al trono se encuentra entre los nahuas de Tenochtitlan y Tezcoco, pues los futuros gobernantes tenían que realizar una serie de ritos de paso en el denominado Tlacatecco (Olivier, 2006: 199-225). De acuerdo con la propuesta de Ló-
}

Según nos menciona Maarten Jansen, la palabra $\tilde{n} u h u$ significa "dios", pero debido a los cambios tonales característicos del mixteco, ñuhu puede significar también "tierra" o "fuego" (1982: 295). Sin embargo, el concepto de $\tilde{n} u h u$ empleado en la religión mixteca se refiere, por lo general, al mundo sagrado, a lo divino y, en algunos términos registrados por Alvarado, la palabra mixteca para "Ymagen del diablo o ydolo" es naa ñuhu o naa nidzanahata ñuhu (Jansen, 1982: 296; Alvarado, 1962: $130 \mathrm{v}$ ).

Para Jansen, el bulto con cabeza de Nuhu parece ser equivalente al que no tiene figura que lo identifique, "bulto esférico simple”, como él lo llama (1982: 319). Supone, entonces, que el concepto $\tilde{n} u h u$, "cosa sagrada", "dios", está implícito en el bulto redondo y, por lo tanto, se suprime su imagen en la mayoría de los casos. Más adelante, este mismo autor menciona que los fundadores de las dinastías pudieron haber sido considerados como ñuhu, por lo que, en algunos casos, los ancestros fundadores de las dinastías fueron equiparados con las fuerzas de la

pez Luján (2006: 271-293), el edificio llamado Tlacatecco en las fuentes podría corresponder con la hoy conocida Casa de las Águilas, lugar en el que los futuros tlahtoque realizaban autosacrificios y penitencias durante los rituales previos a la entronización. Creo, como algo probable, que en la Casa de las Águilas también se encontraban los bultos sagrados de Huitzilopochtli y Tezcatlipoca. 
naturaleza (ibidem: 324). Por lo tanto, para Jansen, el culto al bulto circular es un culto al $\tilde{n} u h u, \mathrm{y}$ como $\tilde{n} u h u$ fueron considerados tanto las fuerzas de la naturaleza como los fundadores de dinastías (ibidem: 325). Sobre estos comentarios surgen, sin embargo, algunas dudas. Para este autor, los bultos de Nuhu son una referencia genérica a un bulto divino o a un bulto que tiene un "dios", sin reparar en el contenido específico que puedan guardar. Por lo que, entonces, la función primordial de los bultos, como elementos centrales en la fundación de las dinastías, era establecer el culto a los antepasados y legitimar el poder dinástico.

Más adelante discutiremos sobre el uso y los rituales a los que estaban asociados los bultos sagrados, pero por ahora quisiéramos señalar que, si bien los fardos, efectivamente, pudieron haber sido empleados como símbolos de legitimación por parte de los gobernantes y que a través del culto a ellos se recordaba a los ancestros, es necesario puntualizar que había bultos específicos para un determinado ritual. Por tanto, consideramos que las afirmaciones de Jansen son algo generalizadas y no particu-

larizan en la variedad de bultos que existían y la diversidad de rituales a los que estaban asociados.

Regresando al contenido del bulto de Nuhu, coincidimos con las observaciones de John Pohl en el sentido de que algunas figuras talladas en madera o piedra con la imagen del Ñuhu pudieron haber estado dentro de los envoltorios sagrados. Precisamente, la figura de Nuhu que se conserva en el Museo Etnográfico de Viena bien pudo haber provenido de un bulto sagrado, aunque faltarían mayores datos para comprobarlo (Pohl, 1994: 29).

\section{USOY SIGNIFICADO DE LOS BULTOS EN LA RELIGIOSIDAD MIXTECA}

Existen muy pocos trabajos sobre los rasgos y características principales que tuvo la religión mixteca en la época prehispánica contemporánea. Únicamente contamos con algunas descripciones sobre su cosmovisión, prácticas rituales, sacrificios, algunas festividades e intentos de conformar un panteón de deidades de acuerdo con las fuentes históricas. Entre algunos de los autores que han tratado de conformar una idea acerca de la religión mixteca se encuentran Barbro Dahlgren (1990), Alfonso Caso (1996a) y los estudios pioneros de Martínez Gracida $(1898,1905)$.

Sin embargo, en estos trabajos aún imperaba la idea de que la religión mixteca era muy semejante en mitos y cultos a la mexica o nahua, a tal grado que no se podía distinguir entre un dios azteca y uno mixteca (Caso, 1996a: 61). En otro texto, sin embargo, el mismo autor reconoció que aún quedaba por emprender el estudio de los dioses en los códices prehispánicos ${ }^{8}$.

Sobre este aspecto, Jill Furst (1978) llevó a cabo un análisis muy completo sobre las representaciones de posibles deidades en el Códice Vindobonensis al lograr identificar sus nombres calendáricos a lo largo de varias secciones de este manuscrito. Dahlgren incluso recurrió a los datos proporcionados por otras fuentes históricas, como las Relaciones geográficas o el Proceso inquisitorial de Yanhuitlán, para conformar una visión general sobre algunos dioses (Dahlgren, 1990: 210). No obstante, hoy en día se requieren nuevas investigaciones que tomen en cuenta no sólo los códices y documentos históricos, sino también las actuales manifestaciones religiosas de los mixtecos contemporáneos.

De ninguna manera pretendemos en el presente artículo abordar más sobre esta problemática, pero queremos plasmar algunas propuestas acerca de un aspecto concreto presente en la religiosidad mixteca y que no fue tomado en cuenta por los autores ya mencionados: el significado de los bultos sagrados.

Ya vimos cómo los envoltorios pudieron haber sido considerados un elemento central en la fundación de la dinastía por parte de los principales señoríos mixtecos. Maarten Jansen propone que el culto a los bultos sagrados fue una forma de institucionalizar el culto a los antepasados divinos y de legitimar el poder dinástico (1982: 322). Según nos menciona este autor, en el momento en que los gobernantes ascendían al poder debían realizar las ceremonias a los bultos sagrados que contenían las reliquias de sus antepasados fundadores de sus dinastías:

${ }^{8}$ Alfonso Caso, “Dioses y hombres en la Mixteca”, 1996b: 169. El artículo apareció originalmente en Artes de México, núm. 70-71, México, 1965. 
"Ser descendiente de la pareja original se combina con la obligación de rendir culto a sus bultos" (loc. cit.).

En el Códice Selden, por ejemplo, parece aplicarse muy bien esta idea de Jansen en la fundación de la dinastía de Jaltepec: en las primeras páginas del manuscrito se encuentra el Señor 10-Caña “Águila de Fuego" recibiendo los bultos sagrados de parte de los sacerdotes, cuyo contenido quizá hayan sido las reliquias de sus padres fundadores: un fardo rectangular con la cabeza de la Señora 8-Conejo y un fardo ovalado con el ojo que identifica al árbol donde nació el Señor 2-Hierba (Jansen y Pérez Jiménez, 2000: 109).

Sin embargo, según nuestro parecer, el culto al bulto sagrado no se limitó (o fue exclusivo) a los rituales de entronización por parte de los gobernantes, sino que llegó a constituirse como la principal manifestación de la religiosidad mixteca en diversos ámbitos de la comunidad. Es decir, hemos considerado la posibilidad, de acuerdo con las fuentes del siglo XVI, de que el culto a los dioses mixtecos se hacía principalmente a través de las imágenes guardadas en envoltorios, lo que llegó a conformarse como una práctica común dentro del fenómeno religioso mixteco. Por ejemplo, en el proceso inquisitorial contra el cacique y gobernadores de Yanhuitlán en 1544-1546 están registradas numerosas descripciones de las fiestas, ceremonias y ofrendas que se dedicaban a los dioses-bultos que eran patronos de Yanhuitlán 9 .

Según los testimonios que hemos podido analizar, un grupo de cuatro sacerdotes se encargaba de cuidar y ofrendar a las cuatro deidades o "ídolos" del pueblo de Yanhuitlán. Uno de estos sacerdotes, de nombre Caxaa (que pudiéramos traducir como 1 o 12-Águila) tenía bajo su cargo especialmente el ídolo de Zagui (Dzavui, el dios de la lluvia) y lo describe como un ídolo de piedra al que le ofrecía copal, plumas, hule quemado y sangre. Una vez que terminaba de ofrendarle y pedirle que trajera la lluvia, el sacerdote tomaba las cenizas, las ofrendas, al ídolo mismo y lo hacía un envoltorio y lo guardaba (Procesos..., 1999: 183-184).

\footnotetext{
${ }^{9}$ Procesos por idolatría al cacique, gobernadores y sacerdotes de Yanhuitlán, 1544-1546, 1999.
}

Diego, un indio esclavo que vivía en casa del gobernador don Juan, declara haber presenciado una serie de ceremonias en honor al maíz:

Y que todos los años, a la cosecha de maíz que es por todos santos, en una fiesta del demonio que se llama huicotuta, mandaba el dicho don Juan sacar todos sus demonios y desatados a cada envoltorio mataba una paloma o codorniz o otra ave y sobre ello llevaba al demonio y echábales copal y los dichos papas se sacrificaban juntamente y que otras veces entre el año hace el dicho don Juan las mismas fiestas (ibidem: 181).

A partir de esta importante referencia podemos conocer no sólo el nombre mixteco de la fiesta que se dedicaba a la cosecha de maíz (huicotuta, fiesta del agua), sino también la manera en que eran ofrendadas las imágenes.

Tenemos otra noticia de este proceso que refuerza la idea de que el culto a los dioses en la Mixteca se realizaba principalmente a través de las imágenes guardadas en un tnani o fardo, ya que el encomendero de Yanhuitlán, Francisco de las Casas, había mandado recoger "todos los demonios" que tenían en la región para guardarlos y evitar así los castigos al cacique y gobernadores durante su proceso inquisitorial:
Y este testigo y otros sus compañeros trajeron los dichos de- monios a cuestas y de noche, los metieron en casa del dicho cacique porque así se lo había mandado porque como este testigo y los demás trajeron los dichos demonios un día en amaneciendo fue allá el dicho Francisco de las Casas y Juan de las Casas y el dicho Juanico por mandado abrió las dichas petacas y envoltorios y sacó los dichos demonios en presencia de este testigo y don Juan y de don Francisco Tuer- to y Domingo Estumeca y visto todo lo que habían traído las piedras y demonios echó en una petaca y lo mandó llevar a su casa al dicho Juanico su criado y que este testigo no sabe más y que en ellos habían muchas piedras buenas por ser los mejores diablos y antiguos de esta Mixteca (ibidem: 178).

Desconocemos a ciencia cierta el destino de todas las deidades recogidas por el encomendero y el número exacto de pueblos que le entregaron los bultos, pero definitivamente podemos comprobar que las efigies, esculturas o imágenes de los dioses eran guardadas en los envoltorios sagrados. 
Esta información concuerda con la Geográfica descripción de Burgoa cuando relata el descubrimiento que hace fray Benito Hernández del envoltorio sagrado de Achiutla, que contenía una escultura de la serpiente emplumada denominada ahí como el "Corazón del Pueblo":

[...] era una esmeralda tan grande como un gruesso pimiento de esta tierra, tenía labrada encima una avesita, ó pajarillo, con grandísimo primor, y de arriba à baxo enroscada una culebrilla con el mesmo arte, la piedra era tan transparente, que brillaba desde el fondo, donde parecía como la llama de una vela ardiendo; era antiquísima alhaja, que no había memoria del principio de su culto, y adoración (Burgoa, 1997a, t. 1: 156 v).

Por último, también describe Burgoa que entre los zapotecos de Nexapa, el fraile Alonso de Espinoza había encontrado una cueva en la que había un altar con dos ídolos de cantera a los que se les había ofrecido copal, plumas verdes y navajas de pedernal (1997b: 98r). Lo interesante es que frente a las imágenes había muchas mantas y lienzos en los que seguramente se encontraban envueltos los dioses.

De esta manera podemos pensar que una buena parte del culto a los dioses en la Mixteca — así como en otros pueblos de Oaxaca (tales como Ixcatlán y Nexapa)— se hacía por medio de las imágenes guardadas en los bultos sagrados. Lo interesante es que estos dioses eran ofrendados y reconocidos por la colectividad, pues en todo el señorío de Yanhuitlán, por ejemplo, don Francisco y don Juan ordenaban que se les realizaran ceremonias comunes (Procesos..., 1999: 137).

El tnani, conocido como el "Corazón del Pueblo" en Achiutla, recibía el culto de amplios sectores de la población, pues incluso llegaban visitantes de lugares muy lejanos y de diversas condiciones sociales, lo que convirtió al lugar en una especie de santuario.

Tenemos identificados hasta el momento dos tipos de culto al fardo sagrado. Uno realizado por los señores y gobernantes como parte de los rituales a sus antepasados para fortalecer su linaje durante las ceremonias de entronización, y otro realizado por sacerdotes durante las fiestas anuales en las que se vinculaba a la comunidad en general. Pero, ¿estaremos hablando de un culto diferenciado entre los mixtecos o más bien la extensa variedad de bultos permitía una diversificación de la religiosidad mixteca?

Para los gobernantes, el envoltorio o tnani se convertía en un símbolo de poder, un elemento necesario para fundar pueblos y genealogías desde tiempos primordiales y, desde luego, para legitimar su ascenso al trono por medio de rituales y autosacrificios que lo ponían en contacto no sólo con sus antepasados, sino también con las deidades. Por otro lado, la religiosidad colectiva también manifestaba su culto a los dioses durante las festividades en las que los sacerdotes abrían los envoltorios y sacaban las imágenes que estaban bajo su resguardo. Creo, entonces, que estamos ante una diversificación de la religión.

Según hemos localizado en algunas fuentes, los gobernantes poseían envoltorios heredados de sus antepasados, que eran ofrendados en ceremonias privadas. En el Proceso inquisitorial de Yanhuitlán se menciona que el gobernador don Francisco tenía guardados en su casa "los ídolos” que habían pertenecido a sus padres, así como los propios:

Preguntado para qué efecto los tiene el dicho don Francisco en su casa, dijo que para adorarlos como los adora y que el uno de los dichos ídolos se llama Xioco que es un ídolo envoltorio al cual llama el dicho don Francisco cuando ha de ir a alguna parte y que tiene otros muchos, que no sabe cómo se llama pero que cada noche los adora y se sacrifica (Procesos..., 1999: 164).

De acuerdo con este interesante testimonio, don Francisco poseía bultos sagrados que formaban parte de un culto particular, en el cual pedía la protección de las deidades ahí resguardadas para sus actividades cotidianas.

También se relata que el cacique don Domingo tenía sacerdotes en su casa que estaban a cargo de "veinte adoratorios de ídolos" a los cuales ofrendaban ordinariamente (op. cit.: 173). Por último, la mayoría de los testigos aseveraba que los ídolos resguardados en las casas del cacique y los gobernadores "eran los ídolos de sus padres y los suyos" (ibidem).

Estamos definitivamente ante un tipo de envoltorios que pertenecían a una familia o linaje en particular, que los distinguía de los bultos reconocidos por la comunidad, y que eran guardados en las casas o palacios de los señores a cargo de un grupo de sacerdotes que debían 
cuidarlos. Burgoa da cuenta de un caso muy interesante entre los zapotecos de Nexapa, pues menciona que dentro de la tumba de un importante señor se hallaron dos ídolos "que eran los más estimados del difunto", colocados a un lado de su mortaja junto con braceros y penachos (1997a: 321r).

También podríamos mencionar las detalladas descripciones de Hernando Ruiz de Alarcón durante sus pesquisas entre los nahuas de Guerrero, quien encontró numerosos casos de personas que guardaban celosamente "petaquillas" o "cestoncillos" que contenían objetos sagrados de antepasados difuntos heredados a los hijos y descendientes, en una clara referencia a bultos sagrados familiares (Ruiz de Alarcón et al., 1952: 31 y 32).

En los códices mixtecos (dedicados a relatar las acciones trascendentales y, en ocasiones, sagradas, de los gobernantes) claramente se muestra la existencia de bultos que resguardan a las deidades patronas de un linaje en particular.

Ya vimos más arriba la importancia en el Códice $\mathrm{Nu}$ ttall del bulto de 9-Viento Quetzalcóatl y del tnani que contenía los instrumentos para encender el fuego. Pues resulta que el lugar que sirvió como repositorio final del envoltorio sagrado de Quetzalcóatl fue nada menos que el Templo del Cielo de Tilantongo, por lo que existe una clara continuidad entre la historia de las señoras 3-Pedernal (madre e hija), narrada en estas páginas del Nuttall, con los fundadores primigenios de Tilantongo. De esta manera, 9-Viento Quetzalcóatl quedó instituido como la deidad patrona del linaje de Tilantongo, cuyo bulto sagrado fue resguardado posteriormente por el sacerdote 5-Lagarto durante los primeros años de vida de su hijo 8-Venado Garra de Jaguar (fig. 11).

En los códices dedicados a la vida de 8-Venado es muy clara la significación que tiene el envoltorio como símbolo de legitimación sagrada para este importante gobernante. En la página 52 del Códice Nuttall, 8-Venado recibe un gran envoltorio de parte del señor 4-Jaguar quien, además de colocarle la nariguera de turquesa, le entrega los símbolos de poder que lo legitiman como nuevo gobernante de Tilantongo.

Por lo tanto, el uso y significado de los bultos variaba no solamente de acuerdo con el contenido de los mismos,

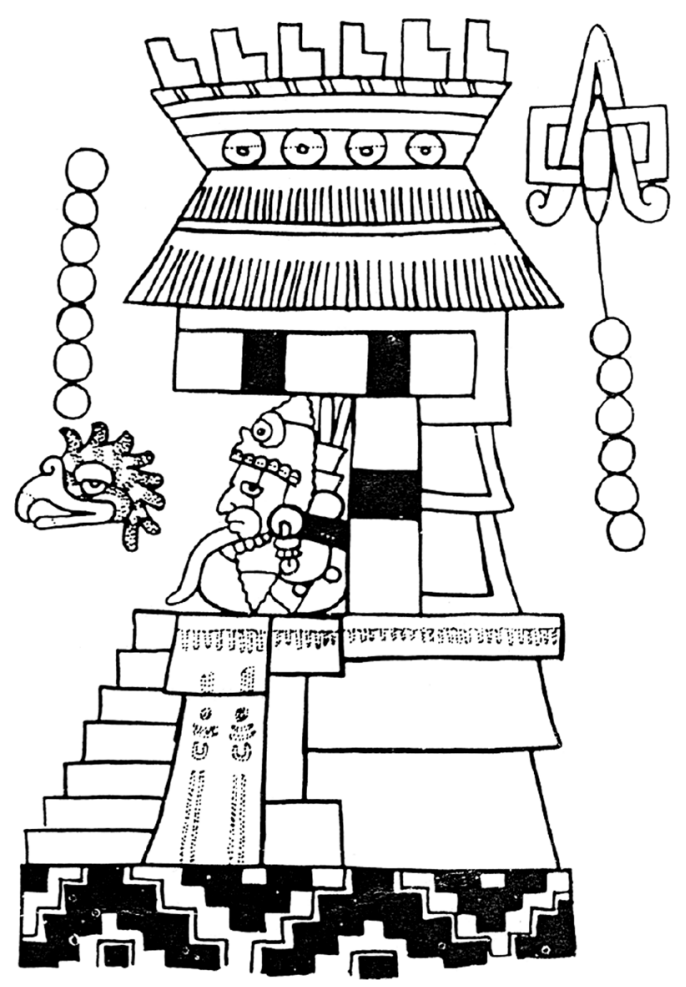

Figura 11. Bulto de 9-Viento Quetzalcóatl dentro del Templo del Cielo de Tilantongo. Códice Nuttall 42-I.

sino que también dependía del grupo social que lo reconocía como parte de su religiosidad. Esto, sin duda, permitía una diversificación del culto religioso entre el pueblo mixteco ya que, por una lado, la comunidad reconocía a su deidad patrona y se identificaba con ella por medio de las fiestas en las que los sacerdotes abrían los envoltorios para que los dioses recibieran el culto en general; pero, al mismo tiempo, existían otros envoltorios que pertenecían al linaje gobernante del pueblo y en los que se guardaban deidades o entidades sagradas que le daban identidad y cohesión a la genealogía por generaciones.

\section{Guerra y otros contextos rituales}

Existen también referencias en los códices de que los bultos sagrados eran llevados a la guerra. En la página 68 del Códice Nuttall, el Señor 8-Venado emprende un viaje de 
seis días consecutivos acompañado de su medio hermano 12-Movimiento y de varios sacerdotes. Uno de los sacerdotes, llamado 2-Mono, carga el bulto junto con otros elementos ceremoniales, mientras que 8-Venado y 12 Movimiento llevan las armas para el combate. Después de pasar por varios lugares, la comitiva llega a una amplia meseta o valle donde se realizan varios sacrificios y ofrendas para garantizar el éxito en la guerra.

De esta manera, el bulto sagrado, junto con otros símbolos ceremoniales, está relacionado con rituales propiciatorios para la guerra o para augurar el buen éxito en alguna campaña militar. Por lo tanto, la fuerza sagrada del bulto tenía que acompañar a cada gobernante no sólo en el momento de su entronización (de ahí la razón de ser ofrendado por los soberanos-sacerdotes antes de tomar posesión del cacicazgo), sino también en situaciones particulares como la guerra, en la que el soberano tenía que recibir esa fuerza proveniente del bulto.

En este sentido, por ejemplo, recordemos que en la $\mathrm{Le}$ yenda de los Soles, los cinco hijos del Sol matan en una guerra a los cuatrocientos mimixcohua y con su sangre se apoderó de un pedernal blanco que brotó de la diosa Itzpapalotl para envolverlo en una manta, lo cargó a cuestas y se fue a combatir en un lugar llamado Comallan (ibidem: 124). De esta manera, entre algunos pueblos de Mesoamérica existe también una asociación directa entre bultos sagrados y guerra.

\section{Peregrinaciones $y$ fundaciones}

Otro uso o empleo de los bultos lo tenemos a través de las peregrinaciones que conducen a la fundación de algún linaje o dinastía, en las que el fardo es transportado, junto con los bastones ceremoniales, por un grupo de sacerdotes.

En las primeras páginas del Códice Sánchez Solís o Egerton (1965) ${ }^{11}$, se describe una larga peregrinación en

${ }^{10}$ Códice Chimalpopoca. Anales de Cuauhtitlan y Leyenda de los Soles, 1992: 123. Traducción directa del náhuatl por Primo Feliciano Velázquez. ${ }^{11}$ Sobre el Códice Egerton véase también Jansen, 1994.

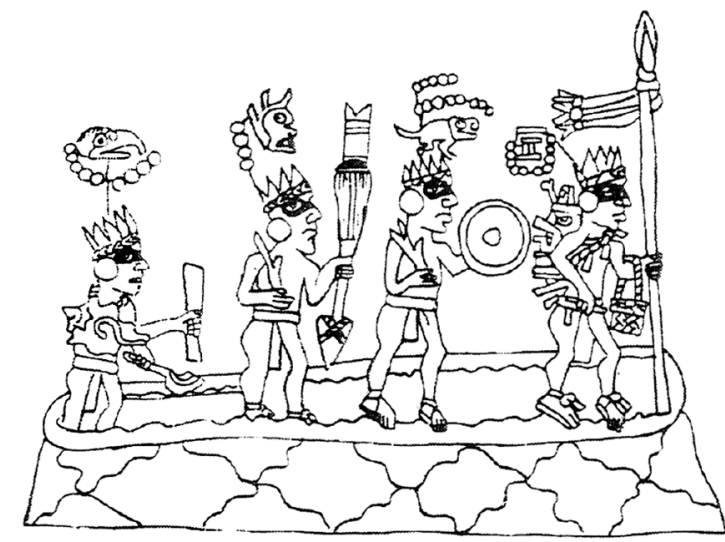

Figura 12. Peregrinación con el bulto sagrado de Quetzalcóatl. Rollo Selden.

la que varios sacerdotes llevan los símbolos sagrados a un sitio llamado Lugar del Jaguar, Ñuu Ñaña, pueblo fundado por los ancestros llamados l-Lagarto. Uno de los sacerdotes que participa en la peregrinación, llamado quizá 1-Venado, carga un envoltorio o mecapal en forma de serpiente que contiene la imagen de Ñuhu. Por lo tanto, el bulto de Ñuhu formó parte de las ceremonias y rituales de fundación que llevaron al establecimiento del señorío representado en este manuscrito.

En el documento conocido como Rollo Selden se representa otra extraordinaria peregrinación con un envoltorio. Se trata de la fundación de un lugar sagrado en la que intervienen cuatro sacerdotes que llevan los bastones ceremoniales y el bulto divino de Quetzalcóatl (fig. 12). En este manuscrito en particular se observa cómo el bulto estaba depositado en un pequeño basamento frente al cual se realiza la ceremonia de encender el fuego como símbolo de fundación. De esta manera, al igual que en el Códice Nuttall, en el Rollo Selden se enfatiza el interés por introducir el culto a Quetzalcóatl por medio de su envoltorio y forma parte, a su vez, de los rituales de fundación de un nuevo asentamiento.

\section{CONCLUSIONES}

En primer lugar, creo que hemos podido establecer una relación clara entre el nombre mixteco tnani, "embolto- 
rio de manta", registrado por Alvarado, con los íconos identificados como "bultos de mantas" en los códices. Todos estos elementos aparecen en las pictografías mixtecas como objetos elaborados a partir de mantas blancas que pueden presentarse en forma redonda u ovalada. Sin embargo, también llegan a registrarse bultos en colores rojo, azul u ocre, dependiendo del códice que los muestra.

Desafortunadamente, no tenemos suficientes elementos para interpretar de manera adecuada la presencia de envoltorios pintados en diversos colores, pero es posible que haya existido una relación directa entre el color del bulto con el contenido específico del mismo. No obstante, en el Códice Nuttall, por ejemplo, no parece existir relación al respecto, ya que a lo largo de dicho códice todos los bultos sagrados aparecen invariablemente con mantas blancas y lo único que los diferencia es la imagen o figura colocada en la parte superior del bulto, como se observa en los casos de los fardos de 9-Viento y el que contiene los implementos para hacer fuego. Por lo tanto, no en todos los códices se puede establecer esta relación entre color y contenido que quizá, en otros documentos, sí pudiera funcionar.

Lo que en definitiva sí creemos haber comprobado es la existencia de distintas clases de bultos dedicados a un ritual, ceremonia o deidad en particular con una orientación religiosa específica. Tal es el caso de las ofrendas y autosacrificios efectuados por los gobernantes a los envoltorios en sus ceremonias previas de entronización, hecho que les significaba la legitimación de su alto estatus y su pertenencia a un linaje que en ese momento gobernaba en el pueblo. Como objetos centrales en los rituales y ceremonias de entronización, los señores rendían culto a sus antepasados, a los fundadores de su dinastía, lo que les permitía llegar al poder y contar con la prerrogativa de gobernar como una facultad heredada de los ancestros.

Otra clase de bultos analizada a lo largo del presente artículo involucraba directamente a la comunidad. Estos fardos guardaban deidades o símbolos que identificaban a todo el pueblo bajo un culto en común y que eran adorados en las fiestas y ceremonias religiosas para propiciar las buenas cosechas y beneficiar las siembras. Recordemos, por ejemplo, al bulto de Dzavui y al bulto de maíz que aparecen en el Códice Selden (fig. 8, p. 84), objetos que seguramente formaban parte de las fiestas o ceremonias que involucraban a toda la comunidad. La imagen de Dzavui, conservada en un envoltorio, era sin duda ofrendada por los sacerdotes para la petición de la lluvia y de los buenos temporales durante los ritos colectivos. El bulto de maíz, a su vez, nos recuerda la narración de Burgoa acerca de la existencia de un culto comunitario a la mazorca para agradecer las buenas cosechas y propiciar mejores siembras en el siguiente periodo calendárico.

Vimos que los envoltorios eran cargados y transportados en peregrinaciones desde tiempos primordiales para la fundación del pueblo o señorío, y que contenían los instrumentos para encender el fuego que consagraba ritualmente el espacio divino para la instauración de la nueva comunidad; o aquellos en que se guardaba la reliquia o imagen de la deidad protectora del linaje.

Encontramos también referencias a bultos que servían para ser llevados a la guerra y dotar a algunos gobernantes de mayor poder durante el conflicto y garantizar su victoria ante sus enemigos. La asociación de un bulto de Nuhu con una flecha y un escudo tal vez nos indica el concepto de la guerra como una actividad sagrada en la que las fuerzas o seres divinos moraban en los objetos llevados a la guerra.

En el caso de los fardos que pertenecían a los gobernantes para su consulta, adoración o protección personal y familiar, podríamos pensar que en ellos se encontraban deidades patronas del linaje o de la dinastía.

Todo ello nos permite demostrar la complejidad de la religiosidad mixteca manifestada a través del bulto sagrado o tnani. Hemos considerado la posibilidad de que los envoltorios hayan sido el elemento central de la religión mixteca y, tal vez, de la tradición oaxaqueña en general pues, al parecer, en toda esta región se encuentran indicios de un culto bastante extendido a los dioses-bultos. No obstante, indagando más a fondo en otras realidades mesoamericanas, observamos que entre los mayas peninsulares también está documentado que las deidades eran colocadas en "petaquillas" y envueltas en un paño para ser entregadas por los sacerdotes a los dueños de estas representaciones denominadas "ídolos" (Landa, 1982: 72). O la aseveración de Mendieta de que el bulto "fue el principal ídolo que tenían en mucha reverencia, y no te- 
nían en tanta como a este a los bestiones o figuras de piedra o de palo que ellos hacían" (Mendieta, 2002: 184).

Finalmente, presentamos a continuación un cuadro que resume el contenido de bultos encontrados en los códices y en las fuentes históricas provenientes de la Mixteca, para resaltar la importancia de las "deidades envueltas en mantas".

\begin{tabular}{|c|c|c|}
\hline Pueblo & Bulto & Contenido \\
\hline \multirow[t]{3}{*}{ Tilantongo } & Bulto de 9-Viento Quetzalcóatl & Un pedernal \\
\hline & Bulto con instrumentos para el fuego & Madero y taladro \\
\hline & Bulto de Nuhu & Imagen de Nuhu \\
\hline \multirow[t]{5}{*}{ Jaltepec } & Bulto dedicado a 8-Conejo & $\begin{array}{l}\text { Reliquias de la señora fundadora, papel pintado, } \\
\text { plumas de guacamaya. }\end{array}$ \\
\hline & Bulto dedicado a 2-Hierba & Reliquias del fundador del linaje, ojo de un árbol. \\
\hline & Bulto de Dzavui & Imagen del dios de la lluvia \\
\hline & Bulto de maíz & Hojas de maíz, mazorcas \\
\hline & Bulto de Nuhu & Imagen de Nuhu \\
\hline Tututepec & Bulto circular azul & Elemento borrado \\
\hline \multirow[t]{10}{*}{ Yanhuitlán } & Bulto de Dzavui & Imagen del dios de la lluvia \\
\hline & Bulto de Tizono & Deidad no identificada \\
\hline & Bulto de Toyna & Deidad no identificada \\
\hline & Bulto de Xitondozio & Deidad no identificada \\
\hline & Bulto de Siquiny & Deidad no identificada \\
\hline & Bulto de Xivisin & Deidad no identificada \\
\hline & Bulto de Quequiyo & Imagen de la diosa 9-Caña \\
\hline & Bulto de Quaquxio & Deidad no identificada \\
\hline & Bulto de Quaquy & Deidad no identificada \\
\hline & Bulto de Xioco & Deidad no identificada \\
\hline Achiutla & Bulto del Corazón del Pueblo & Imagen de Quetzalcóatl \\
\hline Cerro del Águila & Bulto para encender fuego & Madero y taladro \\
\hline
\end{tabular}

\section{Siglas y bibliografía}

AGN, Archivo General de la Nación

Acuña, René (ed.), 1984, Relaciones Geográficas del siglo XVI: Antequera, t. I, Instituto de Investigaciones Antropológicas, Universidad Nacional Autónoma de México, México. (ed.), 1986, Relaciones Geográficas del siglo XVI: México, t. III, Instituto de Investigaciones Antropológicas, Universidad Nacional Autónoma de México, México. Alvarado, fray Francisco de, 1962, Vocabulario en lengua mixteca, reproducción facsimilar con un estudio de Wigberto Jiménez Moreno, Instituto Nacional Indigenista, Instituto Nacional de Antropología e Historia, México. Anders, Ferdinand, Maarten Jansen y Gabina Aurora Pérez, 
1992, Crónica Mixteca: el rey 8-Venado Garra de Jaguar y la dinastía de Teozacoalco-Zaachila. Libro explicativo del llamado Códice Zouche-Nuttall, Sociedad Estatal Quinto Centenario, Akademische Druck-und Verlagsanstalt, Fondo de Cultura Económica, España, Austria, México (Códices Mexicanos, II).

Ayala, Maricela, 2002, El bulto ritual de Mundo Perdido, Tikal, Instituto de Investigaciones Filológicas, Universidad Nacional Autónoma de México, México (Cuadernos del Centro de Estudios Mayas, 27).

Burgoa, fray Francisco de, 1997a, Geográfica Descripción de la parte septentrional del Polo Ártico de la América, edición facsimilar de la obra publicada en 1674, Gobierno del Estado de Oaxaca, Universidad Nacional Autónoma de México, Consejo Nacional para la Cultura y las Artes, Universidad Autónoma Benito Juárez de Oaxaca, Miguel Ángel Porrúa, México.

_ $1997 \mathrm{~b}$, Palestra Historial de virtudes y exemplares apostólicos, edición facsimilar de la obra publicada en 1670, Gobierno del Estado de Oaxaca, Universidad Nacional Autónoma de México, Consejo Nacional para la Cultura y las Artes, Universidad Autónoma Benito Juárez de Oaxaca, Miguel Ángel Porrúa, México.

Caso, Alfonso, 1960, Interpretación del Códice Bodley 2858, Sociedad Mexicana de Antropología, México.

—_, 1964, Interpretación del Códice Selden 3135 (A. 2), Sociedad Mexicana de Antropología, México.

—_, 1966, Interpretación del Códice Colombino y las glosas del Códice Colombino por Mary Elizabeth Smith, Sociedad Mexicana de Antropología, México.

__, 1996a, Homenaje a Alfonso Caso. Obras escogidas, Patronato para el Fomento de Actividades Culturales, México.

__, 1996b, "Dioses y hombres en la Mixteca", Homenaje a Alfonso Caso. Obras escogidas, Patronato para el Fomento de Actividades Culturales, México.

Castillo, Cristóbal del, 2001, Historia de la venida de los mexicanos y de otros pueblos e historia de la conquista, traducción y estudio introductorio de Federico Navarrete, Consejo Nacional de la Cultura y las Artes, México (Cien de México).

Códice Boturini, 1991, reproducción facsimilar de Dinorah Lejarazu y estudio introductorio de Manuel A. Hermann Lejarazu, Gisma, México.

Códice Chimalpopoca, Anales de Cuauhtitlán y Leyenda de los soles, 1992, trad. de Primo Feliciano Velázquez, Universidad Nacional Autónoma de México, México.

Códice Sánchez Solís o Egerton 2895, 1965, editado por Cottie A. Burland, Akademische Druck-und Verlagsanstalt, Graz, Austria (Codices Selecti, 7).
Codex Vindobonensis Mexicanus 1, 1974, Vollständige faksimile-ausgabe im original format, Akademische Druckund Verlagsanstalt, Graz, Austria.

Dahlgren, Barbro, 1990, La Mixteca: su cultura e historia prehispánica, $4^{\mathrm{a}}$ ed., Instituto de Investigaciones Antropológicas, Universidad Nacional Autónoma de México, México.

Freidel, David y Paul Guenter, 2006, "Soul Bundle Caches, Tombs, and Cenothaps: Creating the Places of Resurrection and Accesion in Maya Kingship", en Julia Guernsey y F. Kent Reilly III (eds.), Sacred Bundles: Ritual Acts of Wrapping and Binding in Mesoamerica, Boundary End Archaeology Research Center, Barnardsville, North Carolina, pp. 59-79.

Furst, Jill Leslie, 1978, Codex Vindobonensis Mecanus I: A Commentary, Institute for Mesoamerican Studies, Albany, Nueva York.

Greene, Merle, 1972, manuscrito inédito citado por Ayala, 2002, El bulto ritual de Mundo Perdido, Tikal, Instituto de Investigaciones Filológicas, Universidad Nacional Autónoma de México, México (Cuadernos del Centro de Estudios Mayas, 27).

Guernsey, Julia y F. Kent Reilly III (eds.), 2006, Sacred Bundles: Ritual Acts of Wrapping and Binding in Mesoamerica, Boundary End Archaeology Research Center, Barnardsville, North Carolina,

Gutiérrez Solana, Nelly, 1986, "Sobre el significado de los bultos sagrados y de las figuras incompletas en los códices", Anales del Instituto de Investigaciones Estéticas, vol. 15, núm. 57, pp. 23-35.

Jansen, Maarten, 1982, Huisi Tacu. Estudio interpretativo de un libro mixteco antiguo: Codex Vindobonensis Mexicanus I, Centro de Estudios y Documentación Latinoamericanos, Ámsterdam (Incidentele Publicaties, 24).

_- 1994, La gran familia de los reyes mixtecos: libro explicativo de los códices llamados Egerton y Becker II, Fondo de Cultura Económica, Akademische Druck-und Verlagsanstalt, México, Austria (Códices Mexicanos, IX).

Jansen, Maarten y Gabina Aurora Pérez Jiménez, 2000, La dinastía de Añute. Historia, Literatura e ideología de un reino mixteco, Research School CNWs, Leiden, Países Bajos.

Landa, fray Diego de, 1982, Relación de las cosas de Yucatán, 12a ed., Miguel Ángel Porrúa, México.

López-Austin, Alfredo, 1973, Hombre-Dios. Religión y política en el mundo náhuatl, Universidad Nacional Autónoma de México, México.

López Luján, Leonardo, 2006, La Casa de las Águilas. Un ejemplo de la arquitectura religiosa de Tenochtitlan, 2 vols., Fondo de Cultura Económica, Consejo Nacional para la Cultura y las Artes, Instituto Nacional de Antropología e Historia, México. 
Martínez Gracida, Manuel, 1898, "Mitología mixteca”, en Memorias de la Sociedad Científica "Antonio Alzate", t. XI, 1897-1898, pp. 421-434.

— 1905 , Historia Antigua de la Mixteca, manuscrito inédito microfilmado en la Subdirección de Documentación de la Biblioteca Nacional de Antropología e Historia, serie Manuel Martínez Gracida, rollo 7.

Mendieta, fray Gerónimo de, 2002, Historia Eclesiástica Indiana, 2 tomos, Consejo Nacional para la Cultura y las Artes, México (Cien de México).

Molina, fray Alonso de, 2001, Vocabulario en lengua castellana y mexicana, y mexicana y castellana, $4^{\mathrm{a}}$ ed., edición facsimilar de la obra de 1571, Miguel Ángel Porrúa, México.

Muñoz Camargo, Diego, 1998, Historia de Tlaxcala, paleografía, introducción, notas, apéndices e índices analíticos de Luis Reyes García con la colaboración de Javier Lira Toledo, Centro de Investigaciones y Estudios Superiores en Antropología Social, Gobierno del Estado de Tlaxcala, Universidad de Tlaxcala, Tlaxcala, México.

Nowotny, Karl Anton, 1961, Tlacuilolli: Die mexikanischen Bilderhandschriften, Stil und Inhalt, mit einemen Katalog der Codex Borgia Gruppe, Monumenta Americana III, Berlín.
-, 1966, "Restos de especulaciones místicas de los indios prehispánicos”, en Summa Anthropologica en Homenaje a Robert J. Weitlaner, Instituto Nacional de Antropología e Historia, México, pp. 417-419.

Olivier, Guilhem, 1995, "Les Paquets sacrés ou la mémoire cachée des Indiens du Mexique Central (XVe-XVIe siècles)", Journal de la Société des Américanistes, vol. 81, pp. $105-141$

_ 2006, "The Sacred Bundles and the Coronation of the Aztec King in Mexico-Tenochtitlan”, en Julia Guernsey y
F. Kent Reilly III (eds.), Sacred Bundles: Ritual Acts of Wrapping and Binding in Mesoamerica, Boundary End Archaeology Research Center, Barnardsville, North Carolina, pp. 199-225. , 2007, "Sacred Bundles, Arrows and New Fire. Foundation and Power in the Mapa de Cuauhtinchan No. 2", en David Carrasco y Scout Session (eds.), Cave, City, and Eagle's Nest. An Interpretative Journey through the Mapa de Cuauhtinchan No. 2, Albuquerque, University of New Mexico Press, pp. 281-313.

Pohl, John M. D., 1994, The Politics of Symbolism in the Mixtec Codices, Vanderbilt University, Nashville-Tennessee.

Procesos por idolatría al cacique, gobernadores y sacerdotes de Yanhuitlán, 1544-1546, 1999, ed. de María Teresa Sepúlveda y Herrera, Instituto Nacional de Antropología e Historia, México.

Ruiz de Alarcón, Hernando et al., 1952, Tratado de las idolatrías, supersticiones, dioses, ritos, hechicerías y otras costumbres gentílicas de las razas aborígenes de México, notas, comentarios y estudio de Francisco del Paso y Troncoso, Fuente Cultural, México.

Smith, Mary Elizabeth, 1973, Picture Writing from Ancient Southern Mexico. Mixtec Place Signs and Maps, University of Oklahoma Press, Norman.

Stenzel, Werner, 1972, "The Sacred Bundles in Mesoamerican Religion", Actas del XXXVIII Congreso Internacional de Americanistas, vol. II, Stuttgart, pp. 347-352.

Torquemada, fray Juan de, 1975, Los veinte y un libros rituales y Monarquía Indiana, 7 vols., ed. preparada por Miguel León-Portilla, $3^{a}$ ed., Universidad Nacional Autónoma de México, México.

Troike, Nancy P., 1974, The Codex Colombino-Becker, tesis de doctorado no publicada, Universidad de Londres, Londres. 